\section{Fagervikin kiinalaisen huvimajan kolme tulkintaa: maisema, maku ja matka}

\author{
Seppo Sivonen
}

Fagervikin ruukinkartanon pohjoispuolella on englantilaistyyppinen maisemapuutarha, johon sillan välityksellä liittyy Brännäsholmin saari. Sen länsirannalla sijaitsee Suomessa harvinainen kiinalainen huvimaja, jonka rakennutti eurooppalaisten esikuvien mukaisesti 1786 tai 1787 Fagervikin kartanon perijä, vapaaherra Mikael Hisinger (1758-1829). ${ }^{1}$

Pohdin artikkelissani Fagervikin kiinalaisen huvimajan rakentamisen motiiveja maisemaan, makuun ja matkantekoon liittyvien selitysmallien kautta. Lähtökohtanani on chinoiserien uusi tutkimus-keskustelu, jota on käyty erityisesti Englannissa. Kun chinoiserien aikaisempi taidehistoriallinen tutkimus on hakenut sen yhteyksiä rokokoohon ja barokkiin ja taloushistoriallinen tutkimus yhteyksiä idän kauppaan, on uudempi esinehistoriallinen tutkimus tarkastellut chinoiserien suhdetta 1700-luvun kulutusyhteiskunnan makutottumuksiin, muotiin ja kuluttamisen malleihin. Tässä keskustelussa on esitetty, että 1700-luvun idän ja lännen välisen kaupankäynnin synnyttämä Kiina-muoti vaikutti dramaattisesti varhaismodernin Englannin kulutuskulttuurin makutottumuksiin ja Britannian kaupallisen identiteetin rakentumiseen. Näitä ilmensivät myös maisemapuutarhojen kiinalaisrakennelmat ja niiden mahdollistamat kuvitteelliset matkat itään. ${ }^{2}$

Fagervikin maisemapuutarha kiinalaisine huvimajoineen voidaan määritellä muualta Euroopasta Suomeen levinneeksi kulttuuri-innovaatioksi. Innovaatioiden leviämistä tutkineen sosiologi Everett Rogersin mukaan innovaatioiden diffuusio on viestintäprosessi, jossa tieto innovaatiosta leviää sosiaalisen systeemin jäsenille tiettyjen kanavien kautta ja tietyn ajan kuluessa. Innovaatioiden leviämisessä keskeisiä tekijöitä ovat sosiaalisen systeemin normit, viestintätavat, muutosagentit ja mielipidevaikuttajat. Innovaation vastaanottamiseen vaikuttavat $\mathrm{mm}$.

sen omaksujalleen tarjoama taloudellinen ja sosiaalinen arvostus ja yhteensopivuus vastaanottajan olemassa oleviin arvoihin, aikaisempiin kokemuksiin ja tarpeisiin. ${ }^{3}$

Rogersin innovaatioiden diffuusioteoriaa soveltaen tarkastelen artikkelissani keskeisiä mielipidevaikuttajia ja viestintäkanavia, joiden kautta anglo-kiinalaisen puutarhan maisemaihanne ja chinoiserie-muoti levisivät Fagervikiin. Lisäksi pohdin kuinka hyvin ne sopivat Mikael Hisingerin aikaisempien kokemusten, arvojen ja tarpeiden kanssa ja Fagervikin kiinalaisen huvimajan suhdetta tulkintaan, jonka mukaan kiinalaisrakennelmat toimivat allegorisina, kosmopoliittisuut- 
ta määrittävinä matkakokemuksina. Kiinan ihailua käsittelevässä taustaluvussa määrittelen tarkemmin chinoiserien kontekstissa maiseman kauneuden, makutottumusten ja matkustamisen sisältöjä.

Työni tärkeimpinä lähteitä ovat chinoiserieta, maisemapuutarhoja ja Fagervikin kartanoa käsittelevä tutkimuskirjallisuus, Mikael Hisingerin Euroopan matkapäiväkirja ja 1700-luvun anglo-kiinalaisen puutarhan teoreetikkojen julkaisut. Fagervikin maisemapuutarhan perustamisen kannalta on valitettavaa, että Mikael Hisingerille saapuneet kirjeet ja muu häntä koskeva aineisto on kadonnut. Tästä puutteesta huolimatta käyttämäni lähdeaineisto antaa hyvät mahdollisuudet arvioida uudella tavalla Fagervikin kiinalaisen huvimajan eri selitysmallien kattavuutta.

\section{Kiinan ihailu}

Vaikka Fagervikin kiinalainen paviljonki on Suomessa erikoisuus, eivät vastaavanlaiset rakennukset olleet sitä Euroopan hallitsijoiden ja säätyläisten puutarhoissa 1700-luvulla. Kiinalaistyyppiset rakennelmat liittyivät laajempaan 1600- ja 1700-luvulla Euroopassa vallinneeseen Kiinan ihailuun, joka ilmeni runoilijoiden, kirjailijoiden ja valistusajan filosofien, kuten Leibnitzin ja Voltairen kiinalaisen yhteiskunnan ja sen moraaliarvojen arvostamisessa. Taiteellisena tyylisuuntauksena rokokoohon vaikutteitta antanut chinoiserie ilmeni vahvimmin taidekäsityössä ja kasvaneessa kiinnostuksessa kiinalaista posliinia, lakkahuonekaluja, silkkiä, seinäpapereita ja asusteita kohtaan. ${ }^{4}$

Eurooppalaisen maisemapuutarhan historiassa chinoiseria edustaneet kiinalaistyyppiset rakennukset kuuluivat osana anglo-kiinalaiseen (jardins anglo-chinois) maisemapuutarhasuuntaukseen, joka levisi 1700-luvun jälkipuoliskolla Englannin ja Ranskan ohella Keski-Eurooppaan, Venäjälle, Välimeren maihin ja pohjolaan, erityisesti Tanskaan ja Ruotsiin. Ranskalaiseen muotopuutarhaan verrattuna anglo-kiinalainen puutarha pyrki häivyttämään lineaaristen elementtien suunnitelmalli-suuden ja tavoitteli luonnon ylevöittämistä ja imitoimista korostaakseen sen runollisuutta. Nimityksen jardins anglo-chinois antoivat ranskalaiset puutarhakirjailijat, jotka halusivat termillä horjuttaa englantilaisten merkitystä maisemapuutarhan innovoijana.

Tämä synnytti omana aikanaan vilkkaan keskustelun kanaalin molemmin puolin. Ranskalaisten puutarhateoreetikkojen mukaan länsimaalaisten Kiinan matkaajien kertomukset osoittivat maisemapuutarhan alkuperän olevan paljon vanhemmassa kiinalaisessa puutarhatraditiossa. Tämän näkemyksen englantilaiset whig-intellektuellit kiistivät ja tähdensivät englantilaisten ja kiinalaisten näkemysten eroja puutarhojen suunnittelussa. Heidän mukaansa kiinalainen puutarha oli luonnollisuudestaan huolimatta yli-liioitteleva, pakotettu ja keinotekoinen verrattuna englantilaisen maisemapuutarhan maltillisempaan ja hienovaraisempaan luonnon rekonstruoimiseen. ${ }^{5}$

Maisemapuutarhan alkuperää koskevista erilaisista tulkinnoista huolimatta sen suosio kasvoi Englannissa ja Manner-Euroopassa samanaikaisesti kun chinoiserie löi leimansa 1700-kulutuskäyttäytymiseen. Idästä tuotujen eksoottisten tuontitavaroiden tai niiden jäljitelmien kulutus lisääntyi säätyläisten lisäksi kasvavan keskiluokan keskuudessa ja yhdistettiin uuteen moderniin yksilöllisyyteen ja sivistyneeseen elämäntapaan. Kun vanhoillisten taholta chinoiseria arvosteltiin vieraana ja groteskina, kutsui Englannin hovin puutarha-arkkitehti William Chambers 
(1723-1796) idän luksusta sivistyksen näyttämöksi. ${ }^{6}$

Chinoiserien ja Britannian 1700-luvun kulutusyhteiskunnan suhdetta tutkinut David Porter toteaa, että kiinalaistyyli ja sen liioittelevaisuus edustivat Britanniassa 1700-luvun puolivälissä klassisesta traditiosta eroavaa vastakulttuuria ja makua. Talouselämän nopeat muutokset 1700-luvun alkupuolella mahdollistivat uudenlaisen luksuksen, joka korvasi vanhan antiikin hallitsevan aseman sosiaalisen statuksen markkeeraajana. Kun perinteisesti yhteiskunnan eliitti arvosti omistamiensa arvotavaroiden ikää ja kestävää patinaa, saattoi Kiinasta tuotu posliiniesine tai huonekalu henkiä samanaikaisesti vanhaa ja modernia, olla uusi ja eksoottinen ja kertoa samalla kaukaisen idän vanhasta ja arvostetusta kulttuuriperinnöstä. ${ }^{7}$

Chinoiserien tutkija, taide- ja kulttuurihistorioitsija Vanessa Alayrac-Fielding toteaa, että kiinalainen posliini kertoi narratiivisena objektina visuaalisen tarinan, kun lukuisat posliiniesineiden motiivit kuvasivat Kantoniin ankkuroituneita tai Kiinan rannikolla purjehtineita kauppa-aluksia ja kuvitteellisia näkymiä kiinalaisesta maaseudusta ja arkielämästä. Alayrac-Fieldingin mukaan
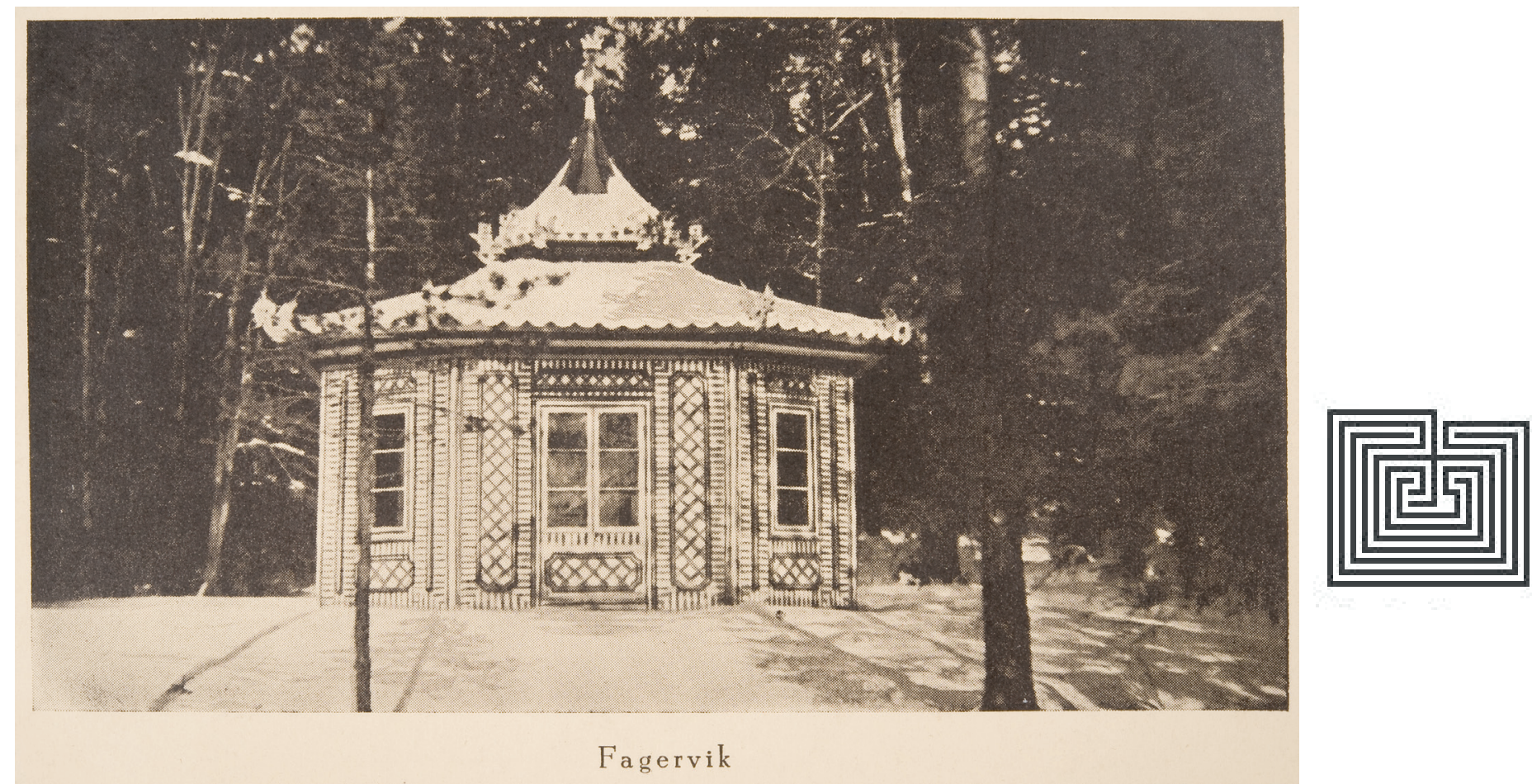

\section{Kuva 1. Fagervikin kartanon kiinalainen huvimaja. Historian kuvakokoelma, Museovirasto.}

1700-luvulla hyvin suosittujen meriaiheisten kertomusten ja matkakirjojen tavoin itämaisen posliinin kuvamaailma jäljitti tapahtumaa kuvitteellisesta matkasta itään samalla kun posliiniesine oli aktuaalinen todiste Kantonin-matkasta. Eurooppalaisten kaup- pakomppanioiden tuoma kiinalainen posliini oli siis kaukomatkojen tunnuskuva. ${ }^{8}$

Tulkintaa chinoiserien tehtävästä virtuaalisissa idän matkoissa tukee Emile de Bruijnin analyysi brittiylimystön 1700 -luvulla suosimien Italiaan suuntautuneiden opinto- ja 
huvimatkojen, Grand Tourien ja chinoiserien välisistä yhtäläisyyksistä ja eroista. Molemmat vaikuttivat aikansa maku- ja muotitottumuksiin. Kuitenkin Italiaan verrattuna Kiinan saavuttaminen oli psykologisesti vaivalloisempaa, riskialttiimpaa ja kalliimpaa. Samat perheet, jotka laittoivat suuria summia Grand Toureihin ja Italian taideaarteiden hankkimiseen, saivat yhteyden kaukaiseen Kiinaan Itä-Intian kauppakomppanian rahoittajina ja Lontooseen tuotujen kiinalaistavaroiden kuluttajina. ${ }^{9}$

Suomessa chinoiserie jäi ohueksi ja oli määrällisesti niukkaa. Suomalaista chinoiseria tutkinut Jouni Kuurne toteaa Fagervikin puiston kiinalaisen huvimajan ja ruukin kartanon kiinalaisaiheisin tapetein sisustetun salongin edustavan Suomessa tämän suuntauksen huippua. ${ }^{10}$ Fagervikin kiinalaisen huvimajan lisäksi kiinalaisvaikutteisista rakennelmista ja niiden suunnitelmista löytyy Suomessa muutamia esimerkkejä. Gustaf Mauri Armfelt suunnitteli kiinalaista paviljonkia ja siltaa Halikon Joensuun kartanoonsa 1800-luvun alussa. Suunnitelma ei todennäköisesti toteutunut. ${ }^{11}$ Vanhassa Suomessa Viipurin Monrepos'n puistoon rakennettiin kiinalaistyylinen Mariantornin nimellä tunnet- tu huvimaja ja silta $1780-$-luvun puolivälissä. Kiinalaisvaikutteisia huvimajoja oli puutarhahistorioitsija Eeva Ruoffin mukaan myös Viipurin maalaiskunnassa Kiiskilän ja Saarelan kartanoiden puutarhoissa, Cloubergin perheellä Rättijärvellä ja Mäntsälän kartanon puistossa. Ruissalon Marjaniemen huvilan eräälle kalliolle rakennettiin vuonna 1849 näköalapaviljonki, joka muistutti Monrepos'n Mariantornia. ${ }^{12}$

Ehkä suomalaisen chinoiserien vähäisyyden vuoksi ilmiö ei ole laajempana eurooppalaisena kulttuuri- ja yhteiskuntailmiönä kiinnostanut suomalaisia tutkijoita. Tutkimus on rajoittunut harvoihin erillisteemoihin. Kuurnen suomalaista chinoserieta 1700-luvulla käsittelyt artikkeli on keskittynyt koristetaiteisiin. ${ }^{13}$ Kiinalaisesta posliinista chinoiserien kontekstissa on kirjoittanut Heikki Hyvönen teoksessaan Kiinalaista posliinia Suomessa. Chinese Porcelain in Finland (1986). ${ }^{14}$ Suomalaissyntyinen ja Ruotsissa elämäntyönsä tehnyt Osvald Sirén (1879-1966) on kansainvälisesti ansioitunut kiinalaisen puutarha-arkkitehtuurin asiantuntija. Hänen julkaisunsa Gardens of China (1949) ja China and Gardens of Europe of the 18th century (1950) ovat alansa klassikkoja. ${ }^{15}$ Sirénin uranuur- tajan asemaa kiinalaisen taiteen ja puutarhataiteen tutkijana on ansiokkaasti tuonut esille viime vuosina Minna Törmä. ${ }^{16}$ Suomalaisten maisemapuutarhojen kiinalaisvaikutteiden historian tutkijoista on Eeva Ruoffin lisäksi todettava Irma Lounatvuori, joka on selvittänyt myös Fagervikin maisemapuutarhan perustamista ja sen kiinalaispaviljongin suunnittelun taustoja. Hänen mukaansa kiinalaisten tapa nauttia luonnon rikkaista muodoista, sen täydellisistä yksityiskohdista ja vastakohdista toi filosofisen lisän eurooppalaisiin maisema-puistoihin. Tämä heijastui puutarhatyylin anglo-chinois-nimityksessä. Eurooppalaisissa maisemapuutarhoissa kiinalaisen puutarhan kevyet puistorakennelmat olivat suosittuja lainoja. ${ }^{17}$

\section{Sharawagdin käsite}

Ensimmäisiä kuvauksia kiinalaisista puutarhoista Eurooppaan välittivät Kiinassa oleskelleet jesuiitat ja kauppiaat 1500-luvulta lähtien. Espanjalainen Juan González de Mendoza kuvasi 1586 ilmestyneessä Keskustan Valtakunnan historiassaan kiinalaisten mahtimiesten residenssejä, joissa oli suuria puutarhoja, lammikoita ja metsiköitä. ${ }^{18}$ Italialainen Martino Martino kirjoitti 1655 
kiinalaisten olevan äärimmäisen taitavia rakentaessaan puutarhoihinsa keinotekoisia kallioita ja kukkuloita. Tärkeän visuaalisen lisätiedon kiinalaisista puutarhoista toi italialainen jesuiitta Matteo Ripa, joka palatessaan Eurooppaan vuonna 1724 lahjoitti Lontoossa Burlingtonin jaarlille kiinalaisia puutarhoja kuvaavia kaiverruksia. Muutettuaan vuonna 1719 Twickenhamin huvilaan Lontoon länsipuolelle uudisti runoilija Alexander Pope muotopuutarhansa ottamalla mallia Ripan kaiverruksista. ${ }^{19}$

Jesuiittojen yksittäisten kuvausten sijasta englantilainen diplomaatti ja esseisti Sir William Temple (1628-1699) pyrki selittämään kiinalaisen puutarhan esteettistä kokonaisuutta Upon the Gardens of Epicurus -esseessään vuodelta 1685 . Siinä hän toi esille etymologisesti epämääräisen käsitteen sharawadgi (sharawaggi), jonka hän oli omaksunut Kiinassa tai Japanissa matkanneilta hollantilais-kauppiailta. ${ }^{20}$ Englannin 1700-luvun maisemapuutarhaliikkeessä käsite yhdistettiin maiseman epäsymmetrisyyden ja säännöttömyyden kauneuteen. Templen mukaan Englannissa puutarhojen kauneus määräytyi pääasiasiassa tiettyjen suhteiden, symmetrian tai yhdenmukaisuuksien perusteella. Kiinalaiset torjuivat tällaisen täsmällisyyden. ${ }^{21}$

Templen jälkeen vuonna 1712 Joseph Addison lehtikirjoituksessaan Pleasures of the Imagination totesi kiinalaisilla olevan kielessään erityisen puutarhojen kauneutta ilmaisevan käsitteen. Vaikka Addison ei käyttänyt termiä sharawadgi, puhui hän samasta periaatteesta. Moninaisuudessaan kiinalainen puutarha synnytti välittömän mielihyvän tunteen ja antoi rationaalisuuden sijasta tilaa mielikuvitukselle. Addisonille Kina edusti kilpailevaa sivilisaatiota ja universaalisuudessaan maan puutarhojen esteettinen kauneus vetosi hänen mukaansa myös eurooppalaisiin. ${ }^{22}$

Temple ja Addison eivät koskaan itse käyneet Kiinassa. Omakohtaisen silminnäkijän kuvauksen shrawadgista antoi sen sijaan ranskalaisen jesuiitta Jean-Denis Attiret (1702-1768) Pekingistä vuonna 1743 lähettämässään, Euroopassa paljon huomiota saaneessa kirjeessään. Keisarin maisemamaalarina hänellä oli mahdollisuus omakohtaisesti kuvata Pekingin läheisyydessä olleen keisarillisen kesäpalatsi Yuanming Yuanin puutarhojen maisemia ja rakennelmia. ${ }^{23}$ Attiret havainnoi absoluuttisen eron kiinalaisten ja eurooppalaisten puutarhojen välillä. Hän katsoi, että kiinalaiset puutarhat loivat luonnon illuusioita ja epäjärjestyksen kauneutta vailla minkäänlaisia taiteen sääntöjä. Teesinsä hän havainnollisti kuvaamalla yksityiskohtaisesti puutarhojen muotoja ja näkymiä. ${ }^{24}$

Brittiläisessä puutarhasuunnittelussa lisääntynyt tieto kiinalaisten puutarhojen tunnusmerkeistä irtaannutti maan maisemapuutarhojen visualisointia Välimeren piiristä ja erityisesti Italiasta ammennetuista uusklassismin virikkeistä. Suurten maisemamaalareiden, kuten ranskalaisten Nicolas Poussinin ja Claude Lorainin ja italialaisen Salvator Rosan klassiset maisemakuvat, antiikin ihannointi puutarhojen rakentamisessa ja brittiylimystön Grand Tour -matkat Italiaan loivat illuusion brittiläisestä "Rooman valtakunnan" jatkumosta. Idän kaupan kasvun ja chinoiserie-muodin myötä ihailun kohteeksi noussut Kiinan ikivanha kulttuuri antoi vaihtoehtoisen tarttuma-pinnan nousevalle britti-imperiumille integroida se muinaisen Rooman sijasta olemassa olevaan idän suurvaltaan, joka oli kiehtova ja ihailtava ja samanaikaisesti vieras ja salaperäinen. ${ }^{25}$ 

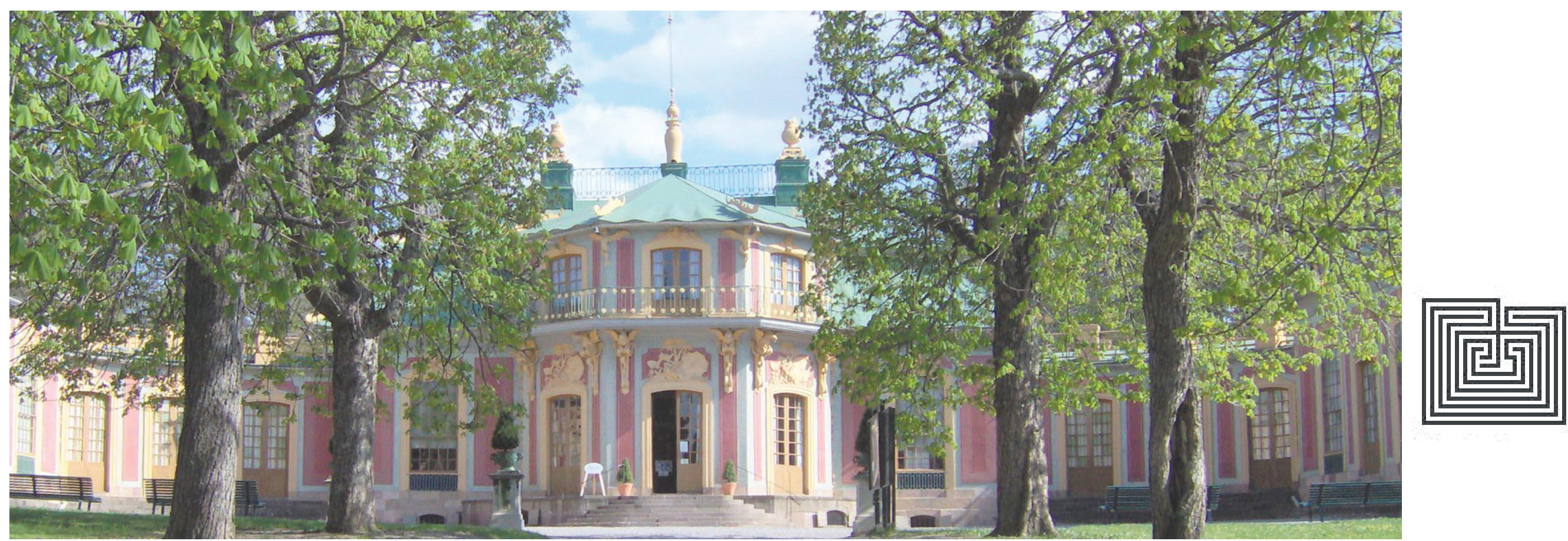

Kuva 2. Carl Fredrik Adelcrantz, Drottningholmin kiinalainen paviljonki, 1763-1769. https://upload wikimedia.org/wikipedia/commons/0/0d/ Kina_slott\%2C_Drottningholm\%2C_Stockholm.jpgKina_slott, Drottningholm, Stoockholm2.jpg

Lopulta eurooppalaisille kiinalaisen maisemapuutarhan prinsiipit 1770-luvulla täsmensi William Chambers, joka ennen Englannin hovin puutarha-arkkitehdin uraa oli itsekin opiskellut Italiassa. Addisonin tavoin Chambers piti sharawagdin ideaa keskeisenä kiinalaisen puutarhan ymmärtä-misessä.
Toisaalta hän toteaa Attiretin Pekingin kirjeen olleen hänen tärkein lähteensä muodostaes-saan omat käsityksensä kiinalaisen puutarhan esteettisistä periaatteista. Niiden mukaan kiinalainen puutarha oli yllätyksellinen ja kokosi yhteen laajan kirjon katselijansa tunnetiloja: nautinnon, järkytyksen, hämmennyksen ja uteliaisuuden. Näkymien vierekkäin asettelu toi esille luonnon moninaisuuden, sen ennustamattomuuden ja aistillisen vetovoiman. ${ }^{26}$ Hovin puutarha-arkkitehtina ja patrioottina Chambers ei kuitenkaan täysin tuominnut maisemapuutarhan säännönmukaisuutta, joka usein yhdistettiin 
itsevaltiuteen. Itse Kiinassa käyneenä hän näki myös Britannian suuruuden riippuvan globaalista kaupankäynnistä ja toivotti chinoiserien tervetulleeksi Englantiin. ${ }^{27}$

\section{Yhteys Ruotsiin ja Englantiin}

William Chambers piti itseään taustansa vuoksi ruotsalaisena. Hän oli syntynyt Göteborgissa skotlantilaisen kauppiaan poikana ja käynyt 1740-luvulla kahdesti Kantonissa Ruotsin Itä-Intian kauppakomppanian palveluksessa. Englannissa Chambers saavutti mainetta lukuisilla töillään. ${ }^{28}$ Näihin kuuluivat $\mathrm{mm}$. Lontoon Kew Gardensin Kungfutsen temppeli ja vuonna 1761 valmistunut, yhä paikallaan oleva 160 jalan korkeuteen kohoava pagodi. Töidensä ja arkkitehtuuria käsittelevien julkaisujensa myötä Chambersista tuli Englannin lisäksi anglo-kiinalaisen maisemapuutarhan tärkein puolestapuhuja Manner-Euroopassa. Englantiin asettuessaan hän piti tiiviitä yhteyksiä myös entiseen kotimaahansa Ruotsiin. Kiinalaisia puutarhoja käsittelevän pääjulkaisunsa $A$ Dissertation on Oriental Gardening (1772) hän toimitti kuningas Kustaa III:lle ja kirjeenvaihtotoverilleen kreivi Carl Frederik Schefferile $^{29}$ (1715-1786), jonka merkitys ranskalaisten valistusfilosofien Kiina-myönteisten yhteiskunnallisten käsitysten välittämisessä Ruotsiin oli tärkeä. ${ }^{30}$ Hänen aikaisemmin julkaisemansa Designs of Chinese buildings, furniture, dresses, machines, and utensils (1757) oli tärkeä opas Tukholman Drottningholmin puiston uuden Kiina-talon sisustamisessa. ${ }^{31}$

Drottningholmin ensimmäinen Kiina-talo oli kuningas Aadolf Fredrikin lahja kuningatar Loviisa Ulriikalle hänen täyttäessään 33 vuotta 24.7.1753. Kuningattaren kerrotaan nähneen yllätykseksi tarkoitetun kiinalaistaIon juhlapäivänsä kävelyretkellä. Näkymän tunnelmaa täydensi kiinalaiseksi prinssiksi puettu kruununperijä Kustaa, joka ojensi kuningattarelle uuden rakennuksen kultaiset avaimet. ${ }^{32}$ Juhlapäivästä kertoo oivallisesti Sakari Topelius Välskärin kertomustensa luvussa "Juhlapidot Kiinassa". ${ }^{33}$ Topeliuksen tekstistä käy ilmi epäily kuningattaren yllätyksen aitoudesta. On todennäköistä, että sen rakentamisesta oli keskusteltu kuningattaren kanssa jo aikaisemmin. Saksalaislähtöisen kuningattaren kontaktit kiinalaismuotiin olivat läheiset. Hänen äidillään Monbijoun linnassa Berliinissä oli kiinalaisittain kalustettuja interiöörejä ja kuningattaren veli Fredrik II
Suuri oli Sanssoucin kiinalaisen teehuoneen rakennuttaja. ${ }^{34}$ Puusta rakennettu ensimmäinen pienehkö kiinalaistalo rappeutui varsin nopeasti. Uusi meidän päiviimme säilynyt Drottningholmin kiinalaistalo rakennettiin vuonna 1763 ja on chinoiserien näyttävin esimerkki pohjolassa. Sen suunnittelusta vastasi arkkitehti Carl Fredrik Adelcrantz..$^{35}$

William Chambersin ja ruotsalaisten maisemapuutarhojen rakentamisen tärkein yhdysside oli kuitenkin ruotsalainen puutarha-arkkitehti Fredrik Magnus Piper (17461824), joka syksyllä 1772 matkusti Englantiin Chambersin oppilaaksi. Oleskeltuaan välillä Italiassa ja Ranskassa Piper palasi Englantiin, missä hän perehtyi kahden vuoden ajan maisema-arkkitehtuuriin uusiin suuntauksiin ja teki tutkimuksia maan hienoimmissa puutarhoissa Painshillissa, Stourhedissa ja Stowessa. ${ }^{36}$ Palattuaan takaisin Ruotsiin vuonna 1780 Piperista tuli kuningas Kustaa III:n hovi-intendentti, joka vastasi kuninkaallisten puutarhojen suunnittelusta. Tässä tehtävässä hän oli keväällä 1781 saanut valmiiksi ehdotuksensa Drottingholmin ja Hagan maisemapuutarhoista. Hänen Hagan puistoon suunnittelemansa kiinalainen temppeli ja kaarisilta jäivät kuitenkin toteutumatta. ${ }^{37}$ 
Kuninkaan lisäksi Piper sai arkkitehtitöilleen muitakin arvovaltaisia asiakkaita. Näihin kuuluivat $\mathrm{mm}$. Chambersin kirjeenvaihtotoveri kreivi Scheffer ja vuonna 1786 avioliiton kautta Nackan Skurun kartanon omistajaksi tullut Carl Råbergh, jonka kanssa Mikael Hisinger teki opintomatkan Eurooppaan vuosina 1783-1784. Kartanonsa luonnonkauneudesta inspiroituneena Råbergh oli ryhtynyt suunnitelmaan sinne englantilaista maisemapuutarhaa, jonka toteuttamiseen hän tarvitsi ystävänsä Fredrik Piperin asiantuntemusta. Skurun puutarhaan oli tarkoitus rakentaa myös kiinalainen paviljonki, jota varten Piper laati kahdet piirustukset. Kun Mikael Hisinger aloitti Fagervikin kiinalaisen huvimajan ideoimisen, turvautui hän puolestaan toverinsa Carl Råberghin apuun ja saikin Råberghin toimittamana Piperin laatimat Skurun kiinalaispaviljonkien piirustukset. Näin Råberghin ja Piperin kautta Fagervikin kiinalaisella huvimajan suunnittelulla oli yhteys Piperin oppi-isään William Chambersiin ja Englantiin. ${ }^{38}$

\section{Mikael Hisingerin puutarhaideaali}

Kun Mikael Hisinger aloitti uuden maisemapuutarhan rakennuttamisen kesällä
1784, loivat ruukinkartanon pohjoispuolinen rantametsä ja Brännäsholmin saari oivalliset edellytykset englantilaistyyppisen, jopa sharawagdi-henkisen puutarhan toteuttamiseen. ${ }^{39}$ Ideoita ja esimerkkejä puutarhahankkeelleen hän sai edellä mainitulla opintomatkallaan Euroopassa. Hisingerin menomatka kulki Ruotsin, Tanskan, Saksan ja Sveitsin kautta eteläiseen Ranskaan ja paluumatka läpi Belgian ja Alankomaiden takaisin Saksaan ja edelleen Tanskan ja Ruotsin kautta Suomeen. Turun akatemiassa opiskellut Hisinger oli vuonna 1777 liittynyt armeijaan ja nimitetty seuraavana vuonna Kuninkaallisen Linnoituskunnan konduktööriksi. Linnoituskunnan arkkitehtiopintoihin liittyi tavallisesti opintomatka Eurooppaan. ${ }^{40}$

Mikael Hisingerin Euroopan-matkapäiväkirjasta käy ilmi hänen mieltymyksensä englantilaiseen maisemapuutarhan kauneusarvoihin. Charles de Geerin omistamasta Stora Wäsbyn puutarhasta Upplannissa hän kirjoittaa, ettei sen perustajalla ollut "hyvää englantilaista ja luonnollista, konstailematonta makua, joka aikaansaa sen, että kaikki elää eri suunnilta nähtynä tuhannella uudella tavalla, mihin silmä ei koskaan väsy." ${ }^{\text {11 }}$ Ranskan Chantillyssa häntä miellyttää eniten englanti- lainen puisto luolineen, kallioineen ja monine hämyisine parhaimman maun mukaan tehtyine puistokujineen. Pohjois-Ranskassa Ermenonvillen puistosta hän kertoo menneensä kotiin ihastuneena ja täysin innostuneena näkemästään luonnosta ja siitä, miten sen kaunistamisessa oli parhainta makua noudattaen seurattu luonnon yksinkertaista mutta viatonta loistoa. Petit Trianonin englantilaista puutarhaa hän piti mitä erikoisimpana. Se oli pieni mutta lumoava. ${ }^{42}$

Stora Wäsbyn puutarhaa koskevasta mielipiteestä käy ilmi, että Mikael Hisinger oli perehtynyt englantilaiseen puutarhasuuntaukseen jo ennen opintomatkaansa. Hän oli voinut saada tietoja suuntauksesta arkkitehtiopinnoissaan Tukholmassa tai jo opiskeluvuosinaan Turun akatemiassa Pietari Kalmilta, joka oli käynyt Englannissa tutustumassa uuteen maisemapuutarhasuunnitteluun 1740-Iuvulla. ${ }^{43}$ Tietonsa hän on voinut ammentaa myös Fagervikin kartanon kotikirjastosta. Mikael Hisingerin isä ruukinpatruuna Johan Hisinger ${ }^{44}$ oli kiinnostunut koriste- ja hyötypuutarhan kehittämisestä ja hankkinut kirjastoonsa runsaasti alan uusinta kirjallisuutta. ${ }^{45}$

Kirjaston kokoelmiin kuului mm. C.C.L. Hirschfeldin moniosainen Théorie de l'art 
des jardins, jonka vaikutus englantilaisen maisemapuutarhan ja sen ihanteiden levittämisessä Skandinaviaan oli tärkeä. Maisemapuutarhaa puolustaessaan Hirschfeld tukeutui englantilaisiin puutarha-teoreetikkoihin ja tunsi myös William Chambersin kirjoitukset. Hän ei kuitenkaan yhtynyt Chambersin tulkintaan kiinalaisen puutarhan periaatteista vaan piti sitä mielikuvituksen tuotteena. ${ }^{46}$ Hirschfeld itse kuvasi kiinalaista puutarhaa käyttämällä lähteenään Attiret'n kirjeen lisäksi mm. ruotsalaisen Carl Gustav Ekebergin (1716-1784) julkaisua. ${ }^{47}$ Ruotsin Itä-Intian kauppakomppanian kapteenina Kantonissa käyneen Ekebergin Ruotsin tiedeakatemiassa julkaisema En Kort Berättelse om den Chineska Landst-Hushållningen (1757) on yksi kiinalaisten puutarhakuvausten 1700-luvun klassikoista. Se oli hankittu myös Fagervikin kirjastoon ja siinä Ekeberg kuvasi lyhyesti mutta tarkasti kiinalaisen puutarhan peruselementtejä. Niiden mukaan puutarhoissa minkään osan ei tarvinnut olla toisensa kaltainen. ${ }^{48}$

Mikael Hisingerin Euroopan-matkallaan näkemät puistot ja puutarhat ja perehtyminen 1700-luvun puutarhakirjallisuuteen olivat Mikael Hisingerin puutarhaideaalin ra- kennuspuita, joita hän pyrki toteuttamaan Fagervikin puiston uudistamisessa. Tuohon ideaalin ei riittänyt pelkästään luonnonkauneuden naturalistinen imitoiminen. Kuten Irma Lounatvuori sanoo, Mikael Hisingerin tavoitteena oli rikas, kustavilaisen kauden ideaaleista ja esteettisistä tavoitteista muodostuva romantisoitu puistokokonaisuus, jonka eri osat olivat kuin maalauksia. Puutarhoissa luonnon omaa kauneutta täydensivät puutarhurin omalla "siveltimellään maalaamat" maisemat. ${ }^{49}$

\section{Chinoiserie Fagervikissa}

Vaikka Mikael Hisinger rakennutti Fagervikiin kiinalaisen huvimajan Chambersin ja Piperin ideoihin perustuen, oli hän puutarhaihanteissaan enemmän kiinni maisemapuutarhan uusklassisessa perinteessä kuin William Chambersin esille tuomissa jardins anglo-chinois -ideaaleissa. Tätä tukee myös se, ettei hän opintomatkansa perusteella ollut erityisen kiinnostunut puutarhojen kiinalaisrakennelmista. Hän vieraili Berliinin lähellä Potsdamissa Sanssoucin linnassa ja näki todennäköisesti linnan puistoon Fredrik II Suuren rakennuttaman kiinalaisen teehuoneen, joka oli chinoiserien näyttävimpiä raken- nuksia koko Euroopassa. Päiväkirjassaan hän ei kuitenkaan mainitse mitään teehuoneesta. Hän ei myöskään mainitse Kasselin Wilhelmshöhenin palatsin puiston kiinalaisrakennusten muodostaa kylää, jota oli ryhdytty rakentaman vuonna 1782 arkkitehti Simon Louis Du Ryn johdolla. Kiinalaiskylän rakentamisella haluttiin viitata Euroopassa 1700-luvulla vallinneeseen käsitykseen kiinalaisen maatalouden edistyksellisyydestä. Ja vaikka Hisinger kirjoittaa yksityiskohtaisesti Pariisin Parc Monceaun englantilaisesta puutarhasta, puiston kiinalaista siltaa hän ei mainitse. Päiväkirjan ainoa lyhyt viittaus eurooppalaisten puutarhojen kiinalais-rakennelmiin on Chantillyn linnan puistosta Pariisin ulkopuolella. ${ }^{50}$

Porterin ja Bergin argumentoinnin perusteella voidaankin pohtia Mikael Hisingerin asemoitumista klassisen taidetradition ja chinoiserien kohtaamisessa. Hänen kiinnostuksensa antiikin kulttuuriperinteeseen ja toisaalta rousseaulaiseen luonnonfilosofiaan näyttäytyy matkapäiväkirjassa ja itse Fagervikin maisemapuutarhan toteutuksessa vahvana. Päiväkirja kertoo Hisingerin tunteneen hyvin antiikin filosofien ja runoilijoiden suuruuden. Ollessaan Dresdenissä hän ihailee 
Saksin kuninkaiden antiikin veistosten kokoelmaa ja Kasselissa hän luettelee pitkän listan Weissensteinin linnan puiston antiikin jumalille ja filosofeille omistettuja temppeleitä ja muistohautoja. Trianonin puiston Apollon hevosryhmän hän tietää olevan suuresti arvostetun ja joitakin puiston veistoksia Hisinger pitää itsekin komeina; tosin joukossa oli myös "vähemmän onnistuneita" ${ }^{51}$. Matkan kohokohta on kuitenkin Ermenonvillen puisto, joka oli tunnettu erityisesti Rousseaun haudan ja kauniin ja luonnonmukaisen puistonsa takia. Tätä myös Hirschfeldin arvostamaa puistoa Hisinger kuvaa päiväkirjassaan hyvin tarkasti ja yksityiskohtaisesti: ${ }^{52}$

(a) Puiden ympäröimä, saarella sijaitseva talo. Täällä oli salon des jeux, jossa oli tunnuslause ja sen yläpuolella selitys. Tähän taloon tullessa oli ylitettävä silta, joka tuli kiinni talon kivijalkaan. Talon alla oli eräänlainen luola, josta oli näkymä kohti päärakennusta. Lehtikujaa pitkin saattoi tästä talosta kulkea pitkin rantaa ja myös palata takaisin pienen sillan yli ja seurata kulkureittiä. Pieni vettä tulviva puro seurasi koko matkan lehtikujaa, joka erosi tiheään metsään kulkevasta kulkureitistä.

(b) Pieni jalusta, pienen kohisevan puron vierellä. (c) Vuorella melko varjoisalla paikalla oleva luola. (d) Toinen jalusta

(e) Kulkureitin varrella pieni harmaakivinen asumus, jota ympäröi aitaus. Täältä johti metsään useita pieniä teitä...”53

Luonnon tarjoaminen emootioiden ja kokemusten arvostamisessa Hisinger asettuu hirschfeldi-läiseksi maisemapuistoteoreetikoksi. Puutarhojen tuli olla luontoa täydentäviä filosofoinnin tyyssijoja. Vaikka Hisinger jakaa Hirschfeldin kanssa puutarhojen luonnonfilosofisen ulottuvuuden, on heidän suhtautumisensa puutarhojen eksotismiin erilainen. Hirschfeldiläisessä maisema-puutarhassa kansakunnan hengen ja luonnon kokemisessa ei Euroopan ulkopuolisella eksotismilla ollut tehtävää eivätkä kiinalaiset pagodit tai turkkilaiset kioskit kuuluneet niihin. ${ }^{54}$ Fagervikin maisemapuiston suunnitelmiin sen sijaan kuuluivat kaksi turkkilaiseen tapaan rakennettavaa huvimajaa ja suunnitelmapiirros obeliskista. Näiden toteutuminen on jäänyt epäselväksi. Mutta kuten Irma Lounatvuori sanoo, ensisijaisena tavoitteena Mikael Hisingerillä oli luoda Fagervikiin haaveellis-filosofinen maisemapuisto. ${ }^{55}$ Puutarhassa oli erakkoluola, filosofien käytävä ja goottilainen torni. Missä C.J.L. Almqvistin Fagervikiä kuvaavien runonsäkeiden Delfoin temppeli tai Venukselle pyhitetty temppeli olisivat sijainneet, ei ole tiedossa. ${ }^{56}$

Vaikka Mikael Fagervikin kiinnostus kiinalaismuotiin näyttäytyy matkapäiväkirjassa ohuelta, eli hän kuitenkin kotikartanosaan Fagervikissa monella tavalla Kiinaan liittyvän harrastuneisuuden piirissä. Kartanon kirjastossa oli Ekebergin Kiina-kuvauksen lisäksi useita matkakertomuksia Kiinasta. On syytä otaksua, että oppinut maailmanmies oli lukenut niitä. Kirjastoon sisältyivät Kantonissa käyneen Ruotsin Itä-Intian kauppakomppanian kapteeni Jacob Wallenbergin Min son på galejan ja Linnén oppilaan Pehr Osbeckin (1723-1805) Dagbok öfver en Ostindiska resa ja lisäksi alkukielellä tai ruotsinnoksina puolenkymmentä muuta Kiinan matkakuvausta. ${ }^{57}$ Kiinaan voidaan tavallaan liittää myös Mikael Hisingerin vanhempien harjoittama mulperipuiden viljely ja silkkiäistoukkien kasvatus 1750-luvun lopulla, johon aikaan kalliin tuontisilkin korvaamiseksi innostus silkinviljelyyn Ruotsi-Suomessa oli korkeimmillaan. ${ }^{58}$

Konkreettisin yhteys chinoiserie-muotiin Fagervikissa näkyi kartanon kiinalaisen sa- 
longin sisus-tuksessa. Moniväriset kiinalaisaiheiset tapetit oli hankittu Tukholmasta päärakennuksen 1773 tapahtuneen valmistumisen jälkeen. Jouni Kuurne on päätellyt, että niiden tekijä on tuntenut hyvin chinoiserie-tapettien eurooppalaiset esikuvat. Kuva-aiheissa on esitetty $\mathrm{mm}$. kellomaisia esineitä kantava kiinalaismies, joka on lainaus Jean Pillement'n kuvateoksesta The Ladie's Amusement (1762). Tapettien sommittelu aiheineen muistuttaa ruotsalaisten Strömsholmin ja Säbyn linnojen samanaikaisia seinämaalaussarjoja. ${ }^{59}$ Tukholmasta Johan Hisingerin puoliso Magdalena Hisinger tilasi kartanoonsa myös itämaista posliinia. Chinoiserie-muoti Euroopassa oli säätyläisnaisten suosiossa, ja itämaisten lakkahuonekalujen, seinäpapereiden ja posliinin käytöstä tuli uuden maun ja eleganssin standardi. ${ }^{60}$ On täysin mahdollista, että Magdalena Hisingerillä oli aktiivinen osuus Fagervikin kiinalaisen salin koristelussa. Chinoiserie antoi naisille vapauden luoda yksilöllisiä tiloja, joissa oli lupa rikkoa makutottumusten tiukkoja roolirajoja. Se tarjosi myös naisille mahdollisuuden heidän kosmopoliittisen identiteettinsä vahvistamiseen, vaikka miesten taholta feminiiniseksi ja turhamaiseksi leimattuna chinoiserien ei katsottu uhkaavan miehisyyden perinteisiä linnakkeita. ${ }^{61}$

Chinoiseriesta Fagervikin naisten makuna ja muotina, kertoo perimätieto myös siitä, että kiinalainen huvimaja olisi ollut paitsi Mikael Hisingerin niin myös Johan Hisingerin toisen puolison Johanna Elisabeth Krookin nimipäivälahja ikääntyneelle ruukinpatruunalle. Lahja oli tarkoitettu yllätykseksi. Tarinan mukaan juhlaseurueen lähestyessä veneellä lahdelman rantaa paljastui kaadetun halkopinon takaa kiinalainen huvimaja. Irma Lounatvuori suhtautuu kertomukseen varauksellisesti, koska se muistuttaa paljon tarinaa Tukholman Drottningholmin puiston Kiina-talon avajaisista. ${ }^{62}$ Toisaalta voidaan hyvin olettaa, että tarina Fagervikin huvimajasta yllätyslahjana Johan Hisingerille oli totta; mikä olisi ollut huvimajaa sopivampi lahja Kiinasta kiinnostuneelle Johan Hisingerille. Ehkä se siirsi Tukholmassa aikaansa paljon viettäneen lahjan saajan ajatukset myös Drottingholmin kiinalaistunnelmiin. ${ }^{63}$

\section{Matka Kiinaan}

Vanessa Alayrac-Fieldingin esimerkkinään pitämien kiinalaisten posliiniesineiden tavoin puutarhojen eksoottiset rakennukset toimivat kuvitteellisten matkojen välittäjinä maa- ilman eri kulttuureihin ja kertoivat Britannian kasvavasta siirtomaamahdista. Englannissa ensimmäisenä puutarhojen kiinalaisrakennelmana pidetään Stowen puutarhan pientä kiinalaistaloa, jonka noin vuonna 1738 suunnitteli todennäköisesti arkkitehti William Kent. Kun taloon saavutaan siltaa pitkin, tulkitsee Stacey Sloboda sen vihjeeksi kauppamatkasta Kiinaan ja talon itämaisen sisustuksen viittauksena toiseuteen. Selkeimmillään imperiaalisten ambitioiden visualisoinnin Britanniassa Sloboda näkee William Chambersin töissä Kew Gardensissa, missä kiinalainen pagodi symboloi britti-imperiumin keskustaa ja pagodi yhdessä puiston moskeijan ja Alhambran kanssa brittien kauppaverkostoa idässä ja Välimerellä. ${ }^{64}$

Nämä tulkinnat viittaavat siihen, että chinoiserien synnytti Euroopan ja Kiinan välinen kauppa- ja kulttuurivaihto yhdessä desiginin muuttuvien ideoiden kanssa. Uutta tuottavana, imitoivana ja innovatiivisena chinoiserie tarjosi niin yksilölle kuin kansakunnallekin mahdollisuuden kiinnittyä idän ja lännen väliseen kaupankäyntiin, moderniin kosmopoliittisuuteen ja esteettisen mielihyvän uusiin tiloihin. Sloboda puhuu kiinalaistyylisistä puutarhoista itämaisine motiiveineen "ulkoi- 
sina" tiloina. Ne esittivät Britannian yhteyksiä globaalisti verkottuneeseen kaupalliseen maailmaan, brittien kasvavaan maailmanvaltaan ja kansallisen identiteetin kosmopoliittisuuteen. Anglo-kiinalaisessa puutarha-arkkitehtuurissa brittiläinen kansallismaisema yhdistyi maan imperiaaliseen, kaupalliseen kulttuuriin ja visioihin toiseudesta. ${ }^{65}$

Nämä käsitykset voidaan hyvin sijoittaa myös Ruotsiin, missä vuonna 1731 perustetun Itä-Intian kauppakomppanian tuoma itämainen posliini, seinätapetit, lakkahuonekalut ja silkki loivat vahvan kasvualustan chinoiserie-muodille ja naisten muuttuville kulutustottumuksille. Samalla ruotsalaisten kartanoiden posliinihuoneet, itämaisin aihein koristetut teesalongit ja puutarhojen kiinalaisrakennelmat tarjosivat tiloja siirtyä vertauskuvallisesti Kiinaan ja ihastella kiinalaisen maiseman ja eksoottisen tapakulttuurin usein romanttista tunnelmaa. Kauppakomppanian vuoteen 1813 kestäneen toimintakauden aikana tuhannet merimiehet, kirkonmiehet ja kauppiaat matkustivat Kaukoitään ja toivat silkin, teen ja posliinin lisäksi mukanaan mielikuvitusta kiehtovia kertomuksia vieraasta valtakunnasta. ${ }^{66}$
Hyvän esimerkin chinoiserien luomasta Kiina-tilasta tarjoaa Drottningholmin Kiina-talo ja sen läheisyyteen perustettu "Pikku-Kantonina" tunnettu käsityöläisalue silkinkutojineen ${ }^{67}$ Drottningholmin Kiina-talolla oli selvä yhteys Ruotsin Itä-Intian kauppakomppanian kauppaan Kantonissa ja siihen kuvaan, minkä kirjallisuus, taide ja arkkitehtuuri Keskustan valtakunnasta antoivat. Kuningasperheelle Kiina-talo oli turvapaikka, jonne he saattoivat vetäytyä velvollisuuksista viettämään yksityisempää elämää. Kiinalaismandariinina ensimmäisen Kiina-talon avajaisissa esiintynyt kruununprinssi Kustaa vietti hallitsijana mielellään aikaansa uudessa Kiina-talossa. Hovin Kiina-innostus näkyi myös Drottningholmissa tai Tukholman linnassa järjestetyissä Kiina-aiheisissa teatteri-, ooppera- ja balettiesityksissä. ${ }^{68}$

Englannin ja Ruotsin puutarhojen kiinalaisrakennelmien tavoin Fagervikin kiinalainen huvimaja itämaisine seinätauluineen voidaan nähdä ulkoisena tilana, joka symboloi sekä Ruotsin että Hisingerien kaupallista kansainvälisyyttä. Johan Hisinger ja Mikael Hisinger eivät suoraan olleet tekemisissä Kiinan kaupan kanssa, mutta he olivat osa Ruotsin ja Tukholman kansainvälisesti verkostoitunutta elinkeino- ja virkamieseliittiä. Ruotsissa paljon oleskellut Johan Hisinger kuului ns. Skeppsbronin kauppa-aateliin ${ }^{69}$, joka hallitsi Ruotsin ulkomaankauppaa ja raudanvientiä ja jonka jäsenillä oli läheiset kytkökset Itä-Intian kauppakomppaniaan. Kauppakomppanian voitot sijoitettiin suureksi osaksi maaomaisuuteen ja rautaruukkeihin. Suomessa Teijon kartanon ruukinpatruuna Johan Jakob Kijk (1706 -1777) oli Itä-Intian kauppakomppanian osakas. Ruotsissa Kiinan kaupan mahtimies oli Johan Hisingerin vapaamuuraritoveri, Ruotsin Itä-Intian kauppakomppanian johdossa ollut ruukinomistaja Johan Abraham Grill. ${ }^{70}$ Hänen omistamansa Gådegårdin kartanon englantilaisen puutarhan ja sen kiinalaisen paviljongin suunnitteli Fredrik Magnus Piper 1780-luvun puolivälissä. Tähän aikaan Ruotsissa englantilaisia maisemapuutarhoja kiinalaisrakennuksineen ryhtyivät perustamaan erityisesti vasta aateloidut virkamiehet ja ruukinomistajasuvut. Grillin tavoin Hisingerit kuuluivat tähän viiteryhmään, joka halusi säätynsä mukaisesti asustaa maaseudulla ja palkata rakennushankkeisiinsa maan parhaimmat arkkitehdit ja koristetaitelijat. ${ }^{71}$

Fagervikissa oli mahdollista tehdä matka kiinalaiseen huvimajaan vesiteitse veneellä 
tai siltaa pitkin. Oswad Sirén lienee nähnyt vielä 1940-luvulla kiinalaistyylisiä piirteitä Brännasholmin saareen johtaneessa vanhassa sillassa. ${ }^{72}$ Englannissa kiinalaiset paviljongit sijaitsivat tunnusmaisesti veden äärellä kertoen siitä, että Kiinaan oli matkattava vesiteitse. Samalla kiinalaistyyliset sillat valmistivat siirtymää toiseuteen ja merkitsivät sekä fyysistä että mentaalista matkaa tilasta toiseen. Silta visualisoi siirtymää ja sen ylitys kuvasi matkantekoa. Englantilaisten 1700-Iuvun maisemapuutarhojen lukuisat kiinalaistyyliset sillat alleviivasivat matkanteon mielikuvituksellista ulottuvuutta ja sijoittivat ne kauppamatkoihin. Kiinalainen silta oli mielikuvituksellisen ja kaupallisen ekskursion väline. ${ }^{73}$

Irma Luonatvuori kirjoittaa, että Fagervikin kiinalaispaviljongista ${ }^{74}$ avautui kiehtova näköala järvenselälle ja hiljainen soutu selän yli korosti huvimajan filosofista, eristäytynyttä luonnetta. Valitettavasti huvimajan alkuperäiset seinämaalaukset ovat tuhoutuneet. On kuitenkin syytä olettaa, että niissä on tavoiteltu samanlaista tunnelmaa kuin paviljongin 1880-luvulla valmistuneissa uusissa maalauksissa. Niissä on kuvattu kiinalaista pihaelämää, silkkiviittainen mandariini palvelijoineen, eksoottisia kukkia ja lintuja ja kaksi japanilaista kuvataulua. ${ }^{75}$ Luonatvuoren toteama majan filosofinen ja eristäytynyt luonne soveltuu Mikael Hisingerin tavoittelemaan haaveellis-filosofiseen maisemapuutarhaan. Kuitenkin jos huvimajaa pidetään ennen kaikkea Johan Hisingerille annettuna lahjana, voidaan Slobodan tulkinnan mukaisesti paviljonki ja matka sinne ymmärtää eristäytymisen ja filosofisen tehtävän sijasta pikemminkin lahjansaajan verkostoitumisen ja pragmaattisten liiketoimien kontekstissa.

\section{Tulkinnat}

Olen artikkelissani tarkastellut Suomessa ainutlaatuisen Fagervikin kartanon kiinalaisen huvimajan rakentamista maisemaan, makuun ja matkantekoon liittyvien selitysmallien yhteydessä. Eri selitysten pätevyyttä olen tulkinnut selvittämällä millaisten kanavien ja mielipidevaikuttajien välittämänä englantilaisen maisemapuutarhan ja siihen sisältyneen kiinalaisen puutarhan sharawadgin maisemaihanne ja chinoiserie-muoti Fagervikiin kulkeutuivat. Olen myös pohtinut, kuinka puutarhojen kiinalaisrakennelmien kauppaan ja toiseuteen yhdistetyt tulkinnat sopivat Mikael Hisinge- rin kokemus- ja arvomaailmaan. Mihin tarpeeseen kiinalaisen huvimaja rakennettiin?

Everett Rogersin innovaatioiden diffuusioteoriaa soveltaen tärkeitä mielipidevaikuttajia kiinalaisen puutarhan ideoiden sisällyttämisessä englantilaiseen maisemapuutarhaan olivat William Temple, John Addison ja erityisesti skotlantilais-ruotsalainen William Chambers. Hänen merkityksensä kiinalaisvaikutteisten maisemapuutarhojen ja niiden kiinalaistyylisten rakennelmien leviämisessä Englannin ulkopuolelle 1700-luvun jälkipuoliskolla oli keskeinen. Chambersin itsensä tärkeimpänä inspiroijana oli Kiinassa oleskellut ranskalainen jesuiitta Jean Attiret. Ruotsiin tiiviitä yhteyksiä pitäneen Chambersin kautta anglo-kiinalaisen maisemapuutarhan ideaalit levisivät Ruotsiin, missä Fredrik Magnus Piper sovelsi niitä suunnitellessaan puutarhoja 1780-luvun puolivälissä. Rogersin teorian mukaisesti kiinalaisen puutarhan ideat levisivät Eurooppaan tietyn sosiaalisen järjestelmän piirissä. ${ }^{76}$ Tämän järjestelmän keskiössä olivat idässä työskennelleet ja matkanneet jesuiitat, heidän kirjoituksiaan lukeneet eurooppalaiset puutarhateoreetikot ja näiden näkemyksiä käytäntöön soveltaneet hallitsi- 
jat, ylimystö ja varakas porvaristo. Ruotsissa anglo-kiinalaisen puutarhan kulttuuri-innovaation omaksuivat 1700 -luvulla hovin ja säätyläisten ohella varakkaat suurkauppiaat ja ruukinomistajat. Hisingerit kuuluivat tähän sosiaaliseen ryhmään.

Eeva Ruoff on tulkinnut, että suomalaisessa $1700-$ luvun maisemapuutarhojen suunnittelussa havupuut, kallioiset ranta-alueet ja kävelytiet kuuluivat Kiina-muodin seurauksiin. Näin todettuna Fagervik tarjosi vesi, -kallio- ja kasvillisuuselementteineen luonnolliset edellytykset rakentaa sinne anglo-kiinalaisen puutarhan "kiinalainen maisema". Voidaan myös sanoa, että Mikael Hisingerin maisemapuutarhan ihanteisiin sisältyi sharawadgin mukaisia vivahteita. Mikään ei kuitenkaan viittaa hänen henkilökohtaiseen Kiina-innostukseensa. Hän otti käytännön virikkeitä uuteen puutarhaansa Ermenonvillen puutarhasta Ranskassa ja puutarhataiteen teoreettisia ideoita William Chambersia enemmän C.L. Hirschfeldilta, jonka englantilaiseen maisemapuutarhaan kiinalaiset rakennelmat eivät sisältyneet. Siten Fagervikin maiseman kautta ei voida selittää kiinalaisen huvimajan rakentamista Brännasholmin saarelle.
Aikaisemmat kokemukset ja arvomaailma vaikuttavat uuden innovaation omaksumisen. Ryhtyes-sään opintomatkansa jälkeen suunnittelemaan Fagervikin maisemapuutarhaa Mikael Hisingerilla oli kokemusta Euroopassa 1700 -luvulla vallinneesta chinoiserie-muodista. Hänen täytyi nähdä Euroopan opintomatkallaan kiinalaisrakennuksia enemmän kuin hän niistä kirjoitti. Chinoiserie ympäröi häntä Fagervikin kartanon kiinalaisessa salongissa ja Kiinaa koskeva matkakirjallisuutta oli käsillä kartanon kirjastossa. Englannissa kuten myös Ruotsissa lisääntynyt kaupankäynti Kiinan kanssa oli muuttanut makutottumuksia säätyläisten keskuudessa. Kiinan ikivanhaa sivilisaatiota materialisoivat kulutustavarat, kuten posliini, seinäpaperit, silkki, lakkahuonekalut ja tee eivät olleet vieraita Fagervikissäkään, jonne niitä hankittiin Tukholmasta. Euroopassa uusi mieltymys kiinalaismuotiin kilpaili klassisen taidemaun kanssa. Tässä makutottumusten arvottamisessa Mikael Hisinger oli päiväkirjansa ja puutarhasuunnitelmiensa perusteella enemmän jälkimäisen tradition ihailija ja toteuttaja. Ei ole perusteita pitää chinoiserie-muotia hänen keskeisenä ohjenuoranaan Fagervikin puutarhan ko- konaisideoinnissa, vaikka se olisikin motivoinut kiinalaisen huvimajan rakentamista.

Chnoiserieta ja maisemapuutarhojen kiinalaisrakennelmia on uudemmassa tutkimuksessa lähestytty Britannian 1700-luvun globalisoituvan kaupankäynnin ja tästä johdetun kansakunnan kaupallisen identiteetin muotoutumisen kautta. Materiaalistunut chinoiserie-muoti tarjosi niin kansakunnalle kuin yksilöillekin tilaisuuden osoittaa toiseuden kautta omaa kiinnittymistä moderniin kosmo-poliittisuuteen. Kun vielä 1600-luvun kuluttaminen oli sosiaalisiin velvollisuuksin kuulunut julkinen teko, 1700-luvun uudet kulutustottumukset privatisoivat makutottumuksia ja kertoivat henkilön omasta ja sosiaalisesta noususta. Englannissa chinoiserie ei ollut vain mielikuvituksen siivittämää idän fantasioimista, vaan osa englantilaisessa 1700-luvun kulttuurissa tapahtunutta makujen keskiluokkaistumista. Tätä lähestymistapaa voidaan soveltaa myös Ruotsiin, missä Itä-Intian kauppakomppaniaan kuuluneiden suurkauppiaiden ja ruukkien omistajien kartanot olivat chinoiserie-muodin näyteikkunoita.

Fagervikin kartanon kiinalaisen huvimajan rakentamiseen globaalin kaupan näkökulma tarjoaa maisemaa ja Kiina-muotia täydentä- 
vän selitysmallin. Tässä tulkinnassa Brännasholmin vaihteleva luonnonmaisema ja Fagervikin kartanon chnoiserie-tausta loivat uuden kulttuurituotteen tuomiselle oivallisen innovaatioalustan. Tuo tuote oli kiinalainen huvimaja. Se sopi Mikael Hisingerin aikaisempaan kokemus- ja arvomaailmaan ja tarpeisiin, mutta Kiina-kiinnostuksen näkökulmasta vielä paremmin Johan Hisingerille. Varakkaana ruukinomistajana ja Ruotsin 1700-luvun globaalistuvien kauppaverkostojen edustajana Johan Hisinger tiesi Itä-Intian kauppakomppanian taloudellisen merkityksen Ruotsille. Tämä tulkinta vahvistaa kertomusta siitä, että huvimaja olisi ollut nimipäivälahja Johan Hisingerille, jonka aikana chinoiserie-muoti tuli Fagervikin kartanoon. Vaikka hän ei itse käynyt Kiinassa, saattoi hän tehdä mielikuvituksellisen idän matkan siirtyessään vesitse tai siltaa pitkin poikansa rakennuttamaan kiinalaiseen huvimajaan.

\section{Viitteet}

1 Irma Lounatvuori, "Impressioita Kiinasta". Teoksessa Irma Lounatvuori (toim.) Fagervikin puutarhojen vuosisadat. SKS 2004, 68 - 73; Eeva Ruoff, "Havupuiden ja kalliorantojen kauneus

- kiinalaisia vaikutteitta vanhoissa suomalaisissa maisemapuutarhoissa". Tieteessä tapahtuu 18 (2000), http://wwww.tieteessatapahtuu fi/008/ruoff.htm (22.9.2016).

2 Tutkimuskeskustelusta ks. David Porter, "Monstrous Beauty: Eighteenth-Century Fashion and the Aesthetics of the Chinese Taste", EighteenthCentury Studies, vol. 35: no. 3 (2002), 395 - 411; David Porter, The Chinese Taste in EighteenthCentury England. Cambridge University Press 2010; Stacey Sloboda, Chinoiserie. Commerce and Critical Ornament in Eighteenth-Century Britain. Manchester University Press 2014; Yue Zhuang, Luxury" and "the Surprising" in Sir William Chambers' Dissertation on Oriental Gardening (1772.) Commercial Society and Burke's Sublime-Effect. Transcultural Studies 2 (2013), 45, http://heiup.uni-heidelberg.de/ journals/index php/transcultural/article/view/10072 (19.9.2016)

3 Everett M. Rogers, Diffusion of Innovations. The Free Press. Fourth edition 1995, 10-30, 35-37.

4 Ks. chinoiseriesta yleisesti Madeline Jarr, Chinoiserie: Chinese Influence on European Decorative Art 17th and 18th Centuries. Vendome Press 1981; Dawn Jacobson, Chinoiserie. Phaidon Press 2001; Anne Witchard (ed.), Chinoiserie and British Modernism. Edinburgh University Press 2015. Valistusfilosofien suhteesta Kiinaan ks. D.E. Mungello, Confucianism in the Enlightenment:
Antagonism and Collaboration between the Jesuits and the Philosophers. Teoksessa Thomas H.C. Lee (ed.), China and Europe. Images and Influences in Sixteenth to Eighteenth Centuries. The Chinese University Press 1991, 99-120.

5 Bianca Maria Rinaldi, Ideas of Chinese Gardens: Western Accounts, 1300-1860, University of Pennsylvania Press 2016, 2, 23; Iris Lauterbach, The European Landscape Garden, ca. 1710-1800 (2017), 20, http:///ieg-ego.eu/en/threads/modelsand-stereotypes/anglophilia/iris-lauterbach-theeuropean-landscape-garden-ca-1710-1800/view (3.1.2018). Kiinalaisten vaikutteiden merkityksestä englantilaiseen maisempuutarhaan ks. myös $\mathrm{Yu}$ Liu, Seeds of a Different Eden: Chinese Gardening Ideas and a New English Aesthetic Ideal. Columbia: University of South Carolina Press 2008 ja Liun kritiikistä Timothy Mowl, The American Historical Review, Volume 115, Issue 1 (2010), 192,. httpps:!l! academic.oup.com/ahr/article/115/1/192/15874

\section{(4.1.2018).}

6 Maxine Berg, Luxury and Pleasure in EighteenthCentury Britain. Oxford University Press 2007, 19 20; Zhuang 2013, 51.

7 Porter 2002, 398 - 399; Porter 2010, 20-28.

8 Vanessa Alayrac-Fielding, From the curious to the "artinatural": the meaning of oriental porcelain in 17th and 18th-century English interiors. Miranda 7/2012, 
https://miranda.revues.org/4390 (4.1.2018).

9 Emile de Bruijn, Virtual travel and virtuous objects chinoiserie and the country house. Teoksessa Jon Stobart (ed.), Travel and the British Country House. Cultures, Critiques and Consumption in the Long Eighteenth Century. Manchester University Press 2017, 64.

10 Jouni Kuurne, Chinoiserie Suomessa 1700-luvulla. Teoksessa Suomen Museo 2000. 107. Vuosikerta. Suomen Muinaismuistoyhdistys 2001, 62. 11 Irma Lounatvuori, Gustav Mauritz Armfelt och Åminne. Historisk Tidskrift för Finland 3 (1997), 406. 12 Eeva Ruoff, Monrepos - muistojen puutarha. WSOY 1993, 115-116; Ruoff 2000.

13 Kuurne 2000, 49-63.

14 Heikki Hyvönen, Kiinalaista posliinia Suomessa. Chinese Porcelain in Finland. Museovirasto 1986, 245-256.

15 Osvald Sirén, Gardens of China. Ronald Press 1949; Osvald, Sirén, China and Gardens of Europe of the Eighteenth Century. Ronald Press 1950.

16 Minna Törmä, Enchanted by Lohans: Osvald Sirén's Journey into Chinese Art. Hong Kong University Press, 2013, 145 - 150; Minna Törmä, In Search of Paradise Lost: Osvald Sirén's Scholarship on Garden Art. Teoksessa Michelle Ying-Ling Huang (ed.), The Reception of Chinese art Across Cultures. Cambridge Scholarships Publishing 2014, 115-
129.

17 Lounatvuori 2004, 68.

18 Juan González de Mendoza, The Historie of the Great and Mightie Kingdom of China and the Situation thereof: Togither with the great riches, huge citties, politike gouernement, and rare inuentions in the same. Translated out of Spanish by R.

Parke. London 1588, 27, https://archive.org/details/! historyofgreatmi14151gonz (5.1.2018).

19 Rinaldi 2016, 7, 11, 83-90.

20 Sirén 1950; Giaran Murray, Sharawadg Resolved. Garden History, vol. 26: no. 2 (1998), 211; Yu Liu, The Inspiration for a Different Eden: Chinese Gardening Ideas in England in the Early Modern Period. Comparative Civilizations Review 53 (2005), 94-95.

21 William Temple, Upon the Gardens of Epicuros, Or Of Gardening in the Year 1685, 237-238, httpos:!l! archive.org/details/worksssirwilliam07ttempgoong. (13.9.2016).

22 Joseph Addison, The Pleasures of the Imagination. The Spectator. No. 414, June 25, 1712 http://web.mnstate.edu/gracyk/courses/web\%20 publishing/addison414.htm (18.9.2016). Ks. myös Tony C. Brown, Joseph Addison and Pleasure of "Sharawadgi" English, Language and Literature, vol. 71: no 1 (2007), 171-193.

23 Jean Denis Attiret, A Particular Account of the Emperor of the China's Gardens Near Pekin. London 1752, https://books.google.fi/books?id $=Q t B b A A A A Q A A J \& p g=P A 1 \& l p g=P A 1 \& d q=J e$ an-Denis+Attiret+letter+from+Peking\&source=bl \&ots=dRGyoidoGb\&sig=FShokxnHtt5kzcCEFraY DI JCngo\&hl=fi\&sa=X\&ved =0ahUKEwiR27z65Y KA hVJfiwKHcClBQ $q=J$ ean-Denis\% $\% 20$ Attiret\%20letter\%20from\%20 Peking\&f=false $(11.10 .2016)$

24 Attiret 1752, 8-15, 38.

25 John Dixon Hunt and Peter Willis (eds.), The genius of the place. The English landscape garden 1620 - 1820. MIT Press 1998, 31-33; Rinaldi 2016, 13; de Bruijn 2017, 64; Kinga Szilagyi, The Impact of Chinese Culture on European Landscape Design 2012, http://korny.uni-corvinus.hu/cneucoop full!papers/s1/kingaszilagyị.pdf (30.12.2017). 26 William Chambers, $A D$ dissertation on Oriental Gardening. London1772, https://archive. org/details/disssertationonoroocham (3.10.2016). Chambers 1772, x - xi, 13-30, 39-43; ks. myös Louise Robertson, The 'Pleasing', the 'Terrible' and the 'Surprising': Sir William Chambers's Landscaping Agenda. University of Glasgow Library 2013, https://universityofglasgowlibrary.wordpress. com/2013/07/01/the-pleasing-the-terrible-and-thesurprising-sir-william-chamberss-landscaping-agendal (14.9.2016) 
27 Zhuang 2013, 50-52.

28 Jane Roberts, Sir William Chambers and George

III. Teoksessa John Harris \& Michael Snodin (eds.)

Sir William Chambers. Architect to George III. Yale

University Press 1996, 41-54.

29 Sirén 1950, 67; John Harris, Kineserier i

europeisk arkitektur. Teoksessa Alm Göran Alm (red.),

Kina slott. Bygförlaget 2002; 22-26, 180, 201-206;

Sloboda 2014, 181-187.

30 Osvald Sirén, Kina och den kinesiska tanken i

Sverige på 1700-talet. Lychnos (1948), 22-43; Sten

Lindroth, Svensk Lärdomshistoria. Frititsheden. P.A.

Norstedt \& Söners Förlag 1978, 138-139; Charlotta

Wolff, Carl Fredrik Scheffers brevväxling med franska

fysiokrater. Historisk Tidskrift för Finland 2 (2003),

198, 201.

31 Sirén 1950, 67; John Harris, Kineserier i

europeisk arkitektur. Teoksessa Alm 2002; 22 - 26,

180, 201-206; Sloboda 2014, 181-187.

32 Magnus Olausson \& Marie-Christie Skunce,

Hovliv i fest och vardag. Teoksessa Alm 2002, 328.

33 Z. Topelius, Välskärin kertomuksia. Kolmas osa.

84. painos. WSOY 1998, 94-99.

34 Johan Cederlund, Byggnadernas historia.

Teoksessa Alm 2002, 16, 99.

35 Cederlund (2002), 59-63, 78, 100.

36 Magnus Olausson, Den engelska parken i

Sverige under gustaviansk tid. Piper Press 1993,
191-210; Svenskt Biografiskt Lexikon, Fredrik Magnus Piper,

https://sok riksarkivet.se/sbl//Presentation. aspx?id=7290 (30.9.2016)

37 Sirén, 1950, 193 - 198; Svenskt Biografiskt Lexikon, Fredrik Magnus Piper, https://sok riksarkivet. se/sbl//Presentation aspx?id=7290.(30.9 .2016).

38 Lounatvuori 2004, 81-82.

39 Lounatvuori 2004, 58.

40 Jouni Kuurne \& Irma Lounatvuori, Huvin ja hyödyn vuoksi. Mikael Hisinger Euroopassa 1783-1784. Teoksessa Timo Tuomi (toim.) Matkalla! Suomalaiset arkkitehdit opintiellä. Suomen rakennustaiteen museo 31 (1999), 31; Mikael Hisinger, Halki vanhan Euroopan. Matkapäiväkirja 1783-1784. Toimittanut ja suomentanut Jouni Kuurne. SKS 2012, 10-14, 32-36, 91.

41 Kuurne 2012, 68.

42 Hisinger 2012, 176, 181, 183-184.

43 Riita Koskinen, Suomalainen kartano.

Kustavilaisen ajan säätyläiselämää. SKS. 2013, 73-74.

44 Ennen aatelointia 1770 sukunimi oli Hising.

45 Lounatvuori 2004, 17, 30, 176-177.

46 C.C.L. Hirschfeld, Theorie de l'art des Jardins. Leipzig 1779, 108 -109, http://bibliotheque-numerique. hortalia.org/items/show/93 (13.9.2016).

47 Hirschfeld 1779, 108-118, http:///bibliotheque- numerique.hortalia.org/items/show/93 (13.9.2016); ks. myös Rinaldi 2016, 22-24.

48 Carl Gustaf Ekeberg, En Kort Berättelse om den Chinesiske Landt-Hushållning. Stockholm 1757, 35-36.

49 Lounatvuori 2004, 58, 65.

50 Kuurne 2012, 56; Hisinger 2012, 93-95,

111-113, 177-181.

51 Hisinger 2012, 184.

52 Hisinger 2012, 109-110, 112-113, 177-181, 183-184.

53 Hisinger, 177.

54 Linda, Parshall, C.C.L. Hirschfeld's Concept of the Garden in the German Enlightenment. Journal of Garden History, vol.13: no. 3 (1993), 141-154; Linda Parshall (ed.) Theory of Garden Art. C.C.L. Hirschfeld. University of Pennsylvania Press 2010, 7.

55 Lounatvuori 2004, 54.

56 Ibid.

57 Kuurne 2012, 15-17.

58 Anders Johansson Åbonde, Drömmen om Svensk silk. Silkesodlingens historia i Sverige. Licentiatavhandling Sveriges lantbruksuniversitet. Alnarp 2010, 23 - 52, http:///pub.epsilon.slu.se/2258/1/! Lic_\%.C3\%85bonde absolutsista_tryck_2.pdf (20.9.2016).

59 Kuurne 2001, 50 - 53; Koskinen 2013, 60.

60 Porter 2010, 8; Eugenia Zuroski Jenkins, A Taste 
for China: English Subjectivity and the Prehistory of Orientalism. Oxford University Press 2013, 53-52; Koskinen 2013, 38; Sloboda 2014, 109.

61 Stacey Sloboda, Fashioning Bluestocking Conversation: Elizabeth Montagu's Chinese Room. Teoksessa Denisy Amy Baxter and Meredith Martin (ed.), Architectural Space in Eighteenth-Century Europe, Constructing Identities and Interiors. Routledge 2010,134; Porter 2002, 408.

62 Lounatvuori 2004, 81.

63 Alf Brenner, Ingå, Fagervik, Degerby. En västnyländsk bygdekronika. Karis Tryckeri 1985, 89. 64 Sloboda 2014,159 - 167, 185.

65 Sloboda 2014, 160 - 174.

66 Hedvig Brorsson, The Influence of East India Trade on Swedish Culture and Social Thought: Chinoiserie, Utility and Theory. Stockholm University. Center for Pacific Asia Studies. Working Paper 28. 1992; Kenneth Nyberg, Bilder av Mittens rike. Kontinuitet och förändring i svenska resenärers Kinaskildring 1749-1912. Historiska Institutionen i Göteborg 2001, 35, 90-93; Kristina Söderpalm, Svenska Ost-Indiska Compagniet och den kinesiska vågen. Teoksessa Alm 2002 2, 281 - 284.

67 Arnold Barton, Canton vid Drottningholm. Ett mönstersamhälle för manufakturer från 1700-talet. Arena 1985, 11-19, 31- 33.

68 Alm 2002, 19, Magnus Olausson \& Marie-
Christine Skunce, Hovliv I fest och vardag. Teoksessa Alm 2002, 328 - 339; Inga Lewenhaupt, Teater, opera och balett I Kina slott. Teoksessa Alm 2002, 346 -

355.

69 Koskinen 2013, 37.

70 Jonas Andersson \& Andreas Önnerfors,

Förteckning över svenska 1700-talsfrimurare.

Teoksessa Andreas Önnerfors (red.) Mystiskt

brödraskap - mäktigt nätverk: studier i det svenska

1700-talsfrimureriet.Lunds Universitet. Ugglan,

Minervaserien 12, 196, 205, https://lucris.lub.lu.se/ws/. files/4475255/2603990.pdf.(26.9.2016).

71 Olausson, 1993, 111 - 113; Söderpalm 2002, 283; Koskinen 2103, 38, 74 - 75.

72 Ruoff 2002, http://www.tieteessatapahtuu.fi/008/ ruoff.htm, (22.9.2016).

73 Sloboda 2014, 167 - 169.

74 Lounatvuori 2004 70, 73 - 75.

75 Rogers 1995, 24.

76 Ruoff (2000), http:///www.tieteessatapahtuu fi/008/ ruoff.htm (22.9.2016).

FT, yleisen historian dosentti Seppo Sivonen (Itä-Suomen yliopisto) on tutkimus- ja julkaisutoiminnassaan suuntautunut erityisesti Afrikan ja Aasian historiaan. Temaattisesti painopiste on ollut kolonialismin historiassa ja eri kulttuurien kohtaamisessa. 